particular product such as meat, wool, milk or eggs. Furthermore, much cross-breeding has been done to meet consumer preferences and changing social patterns. It is not the purpose of this article to examine these factors in any detail but to direct attention to the fact that some breeds of our domestic animals are in danger of becoming extinct.

One of the chief aims of the Zoological Society of London is the promotion of the study of breeding of wild animals in captivity. Over the past few years the Society has been concerned about the chances of survival of several British native breeds of domesticated species, as some are represented by only a few small flocks or herds, and in the case of the Norfolk-horm sheep only one flock remains in the world. The Society has set aside an area of about 100 acres of farmland at Whipsnade Park to establish small flocks and herds which are to be bred under expert guidance. Two breeds of cattle (Longhorn and Chartley) are already being maintained and seven breeds of sheep (Cotswold, Norfolk-horn, Lincoln Longwool, Manx Laughtan, Woodlands Whitefaced, Soay and Portland) have been established. Two 'strains' of the Soay breed are being kept. One of these has a dark brown fleece and ewes with horns and was obtained originally from Soay sheep selected by the Duke of Bedford. The other strain, which includes individuals with a light brown fleece, and some hornless ewes, was brought back from Hirta, St. Kilda, in the summer of 1963. The latter form the nucleus of a flock that is intended to typify the Island sheep and will not be selected for any particular character. Not all these breeds of sheep are regarded as being on the verge of extinction and adjustments will be made from time to time to those which will be kept. It is also hoped to have about 10 breeds of poultry, with an emphasis eventually on purely British breeds. At present five breeds, Silver Spangled Hamburg, Golden Campine, Lakenvelder, Sumatra Game and Auracanas (having blue-shellod eggs), are being held at Whipsnade Park.

Great efforts will be made to ensure the success of this scheme-the Gene Bank-and the Society will collaborate with other herd and flock owners in trying to keep the strains viable by the exchange of stock. The Society is anxious that the widest possible use should be made of the animals in this collection; it is not enough that they should exist merely as historic remnants. It is the earnest hope of the Society that they will be of value to scientists investigating a variety of biological subjects. These animals may be useful in the determination of the affinities of existing breeds and for the study of the wider aspects of domestication of animals. It is possible that they may display physiological attributes representing adaptations to particular environments and, perhaps, some peculiarities of metabolism, growth and structure. Certainly these need investigation. The aim of many of these investigations could be achieved by simple procedures involving observation, measurement and sampling of wool or body fluids. The Society will be plessed to put these animals at the disposal of bona fide scientists and will co-operate so far as their resources allow in these investigations. The greater the use to which these animals are put, the greater will be the Society's confidence in the value of this venture.

\title{
OBITUARIES
}

\section{Prof. Charles Baehni}

By the sudden death of Prof. Charles Baehni at Geneva on January 23, Swiss botany has sustained a grievous loss. For many years he played a leading part in the intellectual life of his native city, where he received his early education and where he was destined to occupy high office in the service of the municipality, University and State. At the University he was encouraged and supervised in his first botanical investigations by his eminent predecessor, Prof. Robert Chodat, and in 1932 he was awarded the degree of Dr. ès Sc. In the same year he was appointed as assistant at the Conservatoire et Jardin Botaniques. During 1934-35 he studied in the Botanical Department of the Field Museum of Chicago, and while in the United States he made numerous trips to various parts of the country and accumulated extensive botanical collections. He was appointed conservator of the Botanic Garden at Geneva in 1941 and two years later succeeded Prof. Hochreutiner as director, a post he held until his death. Conjointly with his duties as director of the Gardens he was professor of systematic botany in the University of Geneva, and for a time in the University of Lausanne.

It fell to Brehni to complete the amalgamation of the historical collections which are the basis of some of the most fundamental works on systematic botany. The Boissier Herbarium and Library were moved from their unsuitable and cramped quarters in the University to be placed with the celebrated collections of de Candolle and Delessert in a reconstructed gallery in the Conservatoire, where the maximum use of space was ensured by an ingenious system of mobile cabinets running on rails. By combining these collections a number of rare items of botanical literature became superfluous and these were sold for a considerable sum.

Baehni was the first president of the International Association of Plant Taxonomy and took a leading part in the foundation of this important body at the International Botanical Congress in Stockholm in 1950. He wrote more than a hundred scientific papers and his chief interest was in the Sapotacene, although his contributions extended to a number of other families, including the Ulmaceae, Lacistemaceae and Violaceae. He was also much interested in the legalistic and often controversial intricacies of the International Code of Botanical Nomen. clature and he was a member of the Editorial Committee from 1950. In this capacity he was involved in the preparation of three editions of that basic work. In recognition of his services, which had won him a high international reputation, the University of Geneva recently honoured him by recognizing his professorship as ad personam.

At his home in Geneva and at his residence in the country, Baehni, who was an accomplished pianist, delighted to entertain his friends, and many botanists will remember the warm and genial welcome which they received from Prof. and Mrs. Baehni and their family.

GeORgE TAYLOR

\section{Prof. M. O. P. lyengar}

Prof. M. O. Parthasarathy Iyengar, emoritus professor of botany in the University of Madras, died on December 10, 1963. Five days later he would have celebrated his seventy-seventh birthday. Indian botany has thus lost one of its most eminent leaders; algology has lost an ardent devotee; his students and colleagues have lost an ideal personal teacher, an able research worker and an efficient guide.

Born in Madras on December 15, 1886, Prof. Iyengar took his Master's degree in the University of Madras in 1909. He served as curator of plants at the Madras Museum and joined the Madras Educational Service in 1911. In 1921 he was appointed professor of botany in 
the Presidency College, Madras. He greatly cherished his life-long association with Prof. F. E. Fritsch, Queen Mary College, London, whom he joined in 1929. After receiving his doctorate from the University of London, he returned to the Presidency College and in 1933 took up the chair of botany in the University of Madras.

Prof. Iyengar had an insatiable interest in the study of algae, and he was a pioneer in this field in India. He is rightly regarded as the Father of Indian algology. Although his work was essentially fundamental without any immediate application, his contributions to basic knowledge are outstanding both in their thoroughness and depth. $\mathrm{He}$ was only seeking the intrinsic beauty in Nature's creation and this search gave him all the joy of his life. His meticulous observations on fertilization in Eudorina elegans, the discovery of anisogamous conjugation in Caulerpa in which the biflagellate gametes are discharged en masse in a mucilaginous matrix, the demonstration of a forcible discharge of zoospores in Trichosolen, and the establishment of an isomorphic alternation of generations in Anadyomene and Microdictyon are only a few of his many important contributions. Even to-day our information on the colonial Volvocales of India is largely based on his paper entitled "Contributions to Our Knowledge of the Colonial Volvocales of South India", published in 1933 in the Journal of the Linnean Society.

It was Prof. Iyengar's special privilege to have discovered several new algae, many of which are unique in their structure and reproduction. Among these may be mentioned Characiosiphon, Cladospongia, Cylindrocap sopsis, Dendrocystis, Ecballocystopsis, Fritschiella, Hor midiella, Pseudovalonia (Boergesenia) and Triplastrum. According to Bower, Fritschiella, a highly organized member of the Chaetophorales, is of much significance in understanding the origin of land plants. Characiosiphon is a unique genus characterized by a common envelope enclosing several discrete, naked, uninucleate protoplasts, each with a stellate chloroplast and a large pyrenoid. $\mathrm{He}$ called it a 'protocœnocyte' and considered it intermediate between a typical cœnocyte and a multicellular form. In Cylindrocapsopsis, which is of still greater interest, the quadriflagellate zoospores give rise to unicellular dwarf male and female plants. The dwarf male gives rise to two or four quadrifagellate antherozoids, while the female forms a single non-flagellated egg.

Prof. Iyengar also proposed a new concept of the origin of the filamentous condition in the green algae. He demonstrated that in Ecballocystopsis, Binuclearia and Cylindrocapsopsis the filamentous condition arises by a transverse division of the protoplasts followed by the development of new and complete walls around the daughter cells inside the wall of the mother cell. According to Pascher, it occurs in a similar way in the Myxophyceae.

Prof. Iyengar's research work was chiefly confined to the Chlorophyceae, of which the orders Volvocales and Zygnematales occupied most of his time between 1944 and 1963. Yet, as a man of wide interests, he took it as his mission to train a team of workers in other fields as well. Thus, he initiated Desikachary in the Myxophyceae; Sundaralingam, Doraiswami, Vimla Bai and Saraswathi in the Chlorophyeeae; Balakrishnan and Krishnamurthy in the Rhodophyceae; Venkataraman and Subrahmanyan in the Bacillariophycea $\theta$; Kanthamma and Janet in soil algae; and Veeraraghavan and Philipose in the limnology of Indian waters. He was also interested in the investigation of aquatic fungi and published a few papers on them.

Prof. Iyengar was a Fellow of the Linnean Society, the Indian Academy of Sciences and the National Institute of Sciences of India. He was elected one of the honorary presidents of the eighth International Botanical Congress held in 1954 at Paris, but due to ill-health he could not attend it. He was the first recipient of the Birbal Sahni Gold Medal of the Indian Botanical Society for outstanding contributions to botany and the Sundar Lal
Hora Gold Medal of the National Institute of Sciences of India. At the time of his death, Prof. Iyengar held the office of president of the International Phycological Society as well as the Indian Phycological Society.

Iyengar's sincerity of purpose, placidity of temper, genial disposition, philosophical simplicity and dedication drew the respect of all Indian scientists. His friends and students have immortalized his name by naming new genera and species after him: Iyengaria, Iyengariella, Parthasarathiella, Anabaena iyengarii, Chlamydomonas iyengarii and Scytonema iyengarii may be mentioned as examples. There is also a hyphomycetous genus Iyengarina erected by C. V. Subramanian. The Indian Botanical Society's Commemoration Volume, published in 1946 on the occasion of his sixtieth birthday, contained articles by Fritsch, Bower, Boergeson, Conrad, Gäumann, Crow, Kylin, Svedelius and many others, illustrating the high esteem in which he was held in international botanical circles.

A forceful speaker and a good sportsman, Prof. Iyengar was full of vitality and energy. He seldom missed his game of billiards. Few people excelled him in his spirit of scientific enquiry and self-denial. He was active until his death and even in his advanced years put many young people to shame by his industry and devotion.

\section{P. Maheshwari}

\section{Prof. H. J. Collins}

Writh the death on December 22, 1963, of Prof. H. J. Collins, at the age of sixty-nine, the civil and structural engineering profession in Britain has lost one of its outstanding personalities of the past thirty years. Since his retirement from the Chadwick chair of civil engineering in University College, London, in 1959, Prof. Collins had not enjoyed good health, although he religiously attended engineering reunions at University College, where he was always warmly welcomed.

Horatio John Collins, who was born in Capetown in 1894, always considered himself a Cornishman. His father was a consulting engineer, and this no doubt influenced his son's interests. He began his engineering education at the University of Birmingham in 1911, but his studies were interrupted by the First World War; during 1914-19 he served with the Royal Warwickshire Regiment. For his war-time service he was awarded an M.C.; he was demobilized in 1919 with the rank of major. On returning from the War, he graduated in 1919, and thereupon undertook research work for the Department of Scientific and Industrial Research under the direction of Prof. F. C. Lea; he took his M.Sc. in 1920. During 1920-22 he was an assistant engineer and designer to E. G. Walker, a London consulting engineer; however, in 1922, he returned to research when he once again became an assistant to Prof. Lea. In 1923 he was, for a short time, an engineerdesigner with Simon-Carves of Manchester, but in the same year he began what was to prove a long association with University College, London, when he was appointed a lecturer in structural engineering. He was promoted to senior lecturer in 1926 and to assistant professor in 1929.

As an engineer he had always had considerable sympathy with investigations in public health, and while ho was an assistant professor he designed and equipped the Chadwick Laboratory of Municipal Engineering and Hygiene in University College for postgraduate study; the first higher degree studies in public health engineering were made under his direction. This period saw the beginning of a long association of the laboratory with the Chadwick idea of "instruction in sanitary science".

In 1936 he was elected Chadwick professor in University College; he held the chair for 23 years until his retirement in 1959. During this period he encouraged the development of many research interests in his department; ho maintained a strong interest in public health engineering 